Ann. Biol. anim. Bioch. Biophys., 1978, 18 (2 B), 335-349.

\title{
Fine structure of prefollicular and developing germ cells in the male and female left embryonic chick gonads in vitro with and without androgenic steroids
}

\author{
by Nicole CARLON (1), G. F. ERICKSON ( $\left.{ }^{(}\right)$ \\ Laboratory of Human Reproduction and Reproductive Biology and the \\ Departments of Anatomy and Obstetrics and Gynecology, Harvard Medical \\ School, 45, Shatfuck Street, Boston, Massachusetts 02115, U. S. A.
}

Summary. Pieces of 6- and 8-day male and female left embryonic chicken gonads were cultured in vitro for 17 or 21 days in ovo with and without androstenedione $(\Delta)$, dihydrotestosterone (DHT) and estradiol $17 \beta\left(E_{2} \beta\right)$. Control cultures of female gonads differentiate into typical ovaries. In the cortex, the prefollicular cells elaborate « lining bodies » and the germ cells develop Balbiani bodies, intercellular bridges and meiotic prophase figures. The ovarian cortex of treated female gonads is similar to that of controls.

Control cultures of male gonads differentiate into typical testes. No cortical tissue is observed. In most cases, treatment with $E_{2} \beta, \Delta$, or DHT induces a partial or complete sexreversal in the male gonads. In the cortex feminized by $E_{2} \beta$ or $\Delta$, the fine structure of prefollicular and germ cells is similar to that in females. Although DHT produces an extensive cortical feminization, the ultrastructural features of the prefollicular cells are not typically female. They develop few if any, « lining bodies » and they contain large, outstanding nucleoli and great amounts of RER cisternae filled with a granular substance, suggesting active protein synthesis. Nevertheless, most germ cells differentiated into typical oogonia. These results support the concept that steroids may play a role regulating the differentiation of the prospective bird ovary. The development of the male germ cells into oogonia can be correlated with indirect and/or direct effects on the developing cortex of the added androgens or estrogens. The unique morphological aspect of male sex-reversed pieces, treated with DHT could actually suggest that steroids act directly on the prefollicular cells. In view of these results it is still in doubt whether or not androgens play a role in controlling the initial stages of testicular differentiation.

\section{Introduction.}

Although the factors regulating the differentiation of the bird gonad are not well understood there is evidence suggesting that steroid hormones may be involved (reviewed by Haffen, 1970, 1975).

(1) Present address : Laboratoire d'Histologie et Embryologie II, Faculté de Médecine, 27, boulevard Jean-Moulin, 13385 Marseille Cedex 4, France.

(2) Department of Reproductive Medicine, The University of California San Diego, La Jolla, California 92033, U. S. A. 
This evidence is based primarily on the fact that estrogens and androgens induce a sex-reversal in the left embryonic male gonad of the bird. It is well-established that estrogens injected into male chicken embryos at 4 to 8 days of incubation cause the perspective male restis to differentiate into an ovarian-like cortex (Wolff and Ginglinger, 1935 ; Dantchakoff, 1935 ; Willier et al., 1935). At the electron microscope level the male germinal epithelium develops into a cortex containing typical prefollicular cells and oocytes (Narbaitz, 1971). It is now demonstrated that the sex-reversed male gonads have the capacity to convert ${ }^{14} \mathrm{C}$-acetate into estrone and estradiol (Akram and Weniger, 1967, 1969).

In conjunction with these studies, Wolff et al. (1948) reported the paradoxical finding that a variety of androgens including $\Delta$-4-androstenedione feminize the undifferentiated male chicken gonad in ovo. More recently, Weniger and Zeis (1973) extended these findings by demonstrating that male left chicken gonads feminized by dihydrotestosterone convert also ${ }^{14} \mathrm{C}$-acelate into estrone and estradiol.

In attempt to establish more precisely the morphological effects of some androgens on the bird gonad, we have cultured pieces of male and female chicken left embryonic gonads with and without androgens and estrogen, using an organ culture system which supports gonadal development for up two weeks. The differentiation of the gonads in culture was analyzed at the electron microscope level. A radioimmunoassay study of their steroidogenic potential was carried out during the same experiments (Erickson, unpublished results). The morphological results were compared to those observed in male and female chicken left embryonic gonads in ovo.

\section{Material and methods.}

White leghorn chicken embryos of 6- to 21-days of incubation were used in this study. 2 male and 2 female left gonads were prepared for an in ovo electron microscope study at the following stages : 6, 8,12,14,17 and 21 days of incubation. 6- and 8-day embryos were used in the in vitro experiments (the number of cultures carried out is indicated in table 1).

The sex of 6-day embryos was established from karyotypes of skin and cartilage cells in culture. In 8-day and older embryos anatomical sex is easily recognized.

\section{TABLE 1}

Number of cultures performed according to the day of incubation, sex of embryos and treatment

\begin{tabular}{ccccc}
\hline Cultures & Control & with E2 & with $\Delta$ & with DHT \\
\hline 6-day female $\ldots \ldots \ldots$ & 1 & 1 & 2 & 1 \\
8-day female $\ldots \ldots \ldots$ & 2 & 2 & 2 & 1 \\
6-day male . ....... & 1 & 1 & 2 & 1 \\
8-day male ........ & 2 & 2 & 2 & 2 \\
\hline
\end{tabular}


The gonads were dissected from the mesonephros and culfured as $0.5 \mathrm{~mm}$ diameter pieces of intact gonad (6- and 8-day gonads were cut into 3 and 4 pieces, respectively). Since the sex of 6-day embryos could not be determined immediately, the pieces of gonad from each embryo were cultured separately until the sex was established 48 hrs later ; then, all pieces of the same sex were pooled and cultured together for the remainder of the experiment. Pieces of 8 -day gonads were pooled at the beginning of the culture.

The methods for culturing tissue have been previously described by one of us (Erickson, 1974a). Briefly the tissue was cultured in plastic tissue culture dishes (Falcon) which had been covered with a layer of sterile agar to prevent cellular attachment. 12 to 20 pieces of gonads were incubated submerged in $5 \mathrm{ml}$ of Mc Coy's 5 a medium (Modified: Gibco) supplemented with $2 \mathrm{mML}$-glutamine, 100 units $/ \mathrm{ml}$ penicillin, $5 \mathrm{\mu g} / \mathrm{ml}$ streptomycin sulfate, and $10 \mathrm{p} .100$ fetal calf serum. Fetal calf serum used for all experiments came from the same batch : one $\mathrm{ml}$ contained $36 \pm 2 \mathrm{pg}$ progesterone, $45 \pm 1 \mathrm{pg}$ androstenedione, $123 \pm 4 \mathrm{pg}$ testosterone, $39 \pm 1 \mathrm{pg}$ estrone, and $197 \pm$ $5 \mathrm{pg}$ estradiol (mean \pm SE of 4 determinations) and therefore, the final growth media contained $<20 \mathrm{pg} / \mathrm{ml}$ of the above steroids (Radioimmunoassay procedures used in this study have been previously described by Challis et al., 1973, 1975). Cultures were maintained in a humidified 95 p. 100 air and 5 p. $100 \mathrm{CO}_{2}$ incubator at $37{ }^{\circ} \mathrm{C}$ for a time equivalent to 17 or 21 days of incubation in ovo (for certain fe male cultures only), i.e., 6-day gonads were cultured for 11 days and the 8-day gonads were cultured for either 9 or 13 days.

The gonads were cultured in the presence or absence of one of the following hormones : $3 \mu \mathrm{M}$ (estra-1, 3, 5 (10) -triene-3, $17 \beta$ diol Estradiol $17 \beta$ : E2) $3 \mu \mathrm{M}$ (androst-4-ene-3, 17 dione androstenedione : $\Delta$ ) : $3 \mu \mathrm{M}(5 \alpha$-androstan-17 $\beta$-ol-3ane (dihydrostestosterone : DHT). These steroids (Sigma) were purified by thin layer chromatography and then dissolved in $100 \mathrm{p}$. 100 ethyl alcohol and added to the culture media in a $5 \mu \mathrm{l}$ volume. The culture media were changed every 2 days at which time fresh hormones were added to appropriate dishes. Throughout the culture period pieces were prepared for electron microscope study.

Gonads were fixed for $20 \mathrm{~min}$ at $4^{\circ} \mathrm{C}$ in $3 \mathrm{p} .100$ glutaraldehyde in $0.1 \mathrm{M}$ phosphate buffer containing 1.5 p. 100 sucrose and then postfixed for $30 \mathrm{~min}$. in 2 p. 100 osmium tetroxide (prepared in the same buffer). The gonads were then dehydrated in acetone and embedded in Epon 812 or in Epon-Araldite mixture. Thick sections $(1$ to $1.5 \mu \mathrm{m})$ were stained with paraphenylene-diamine and examined with the light microscope. Thin sections ( 800 to $1000 \AA$ ) were doubly stained with uranyl acetate and lead citrate and examined with a Philips 200 electron microscope.

\section{Results.}

\section{Morphology of gonads in ovo}

Since the results of the present ultrastructural study confirm and extend those reported previously (Narbaitz and Adler, 1966 ; Scheib, 1970 ; Rahil and Narbaitz, 1972), they will not be detailed, but certain interesting points should be underlined. 
Indifferent stage. At 6 days of incubation, sexually undifferentiated left male and female gonads are ultrastructurally indistinguishable. Their medulla is a polymorphic mesenchymal blastema organized into cord-like aggregations. Typical steroidsecreting cells, i.e., cells with large amounts of smooth endoplasmic reticulum (SER), lipid droplets, and mitochondria with tubular cristae, are not observed. The surface of the medullary blastema is covered in part by a thickened germinal epithelium which is composed of primordial germ cells and columnar epithelial cells. Some epithelial cells in the germinal epithelium of both sexes elaborate conspicuous organelles, often called « lining bodies» (as shown in fig. 7). Since « lining bodies » have been observed only in prefollicular cells, they can be used as a specific cytological marker for this cell type (Rahil and Narbaitz, 1972).

Ovary. At 8 days of incubation and thereafter, a thick cortex is developing in the female left gonads (fig. 1). During cortical development the prefollicular cells produce and release large numbers of "lining bodies" into the extracellular fluid. Most oogonia have Balbiani bodies and intercellular bridges by 10 days and some oocytes are in leptotene at 17 days (Carlon et al., 1974). At 21 days (Hatching day) first pachytene stages are observed in oocytes (Narbaitz, 1971). Scattered throughout the 8-day medulla are clusters of relatively undifferentiated interstitial cells. Thereafter, they undergo modifications and acquire the fine structure typical of active steroid-secreting cells (fig. 2). Ovarian interstitial cells occur in large clusters in the medulla and in the mesenchyme beneath the cortex, and they appear to increase markedly in number between 8 and 17 days of incubation.

Testis. The germinal epithelium in the 8-day male gonad has undergone almost complete regression and the medulla is becoming organized into seminiferous cords (fig. 3). No «lining bodies » were observed in the sections we examined. Typical

\section{PLATE I}

FIG. 1. - Photomicrograph showing cortical cord proliferation in the 8-doy ovarian cortex (C) in ovo. The cords contain elongated epithelial cells (the prefollicular cells) and numerous germ cells containing osmiophilic (black) lipid droplets. Clusters of interstitial cells (arrows) and lacunae (L) are visible in the medulla $(M)(\times 320)$.

FIG. 2. - Electron micrograph of a cluster of highly differentiated interstitial cells in the 14-day ovarian medullo in ovo. Large amounts of SER and $(L)$ lipid droplets are evident $(\times 24,750)$.

FIG. 3. - Photomicrograph of an 8-day left testis in ovo. The germinal epithelium has undergone almost complete regression (thin arrows) and seminiferous cords are developing (large arrows) in the medulla. Germ cells with lipid droplets are seen in the seminiferous cords. Typical Leydig cells are not observed $(\times 320)$.

FIG. 4. - Photomicrograph of a 10-day male left gonad in ovo. At this stage, a testicular organization is firmly established. The seminiferous cords are well organized and small clusters of presumptive Leydig-like cells are found in the interstitium (large arrows). Germ cells with juxtanuclear aggregation of mitochondria are also seen (small arrows) $(\times 320)$.

FIG. 5. - Electron micrograph of a presumptive Leydig cell in the interstitium of a 14-day left testis in ovo. Lipid droplets $(L)$ and mitochondria with tubular cristae are present, but SER is scarce $(\times 24,750)$. 

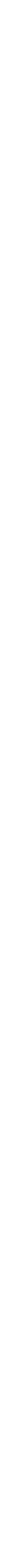
steroid-secreting cells are not found in the interstitium of the 8-day testis. However, in agreement with other studies (Narbaitz and Adler, 1966 ; Scheib, 1970), there are cells inside the seminiferous cords that contain relatively large amounts of SER and lipid droplets. By 10 days of incubation, the germinal epithelium is totally regressed and a rudimentary tunica albuginea is observed. The seminiferous cords are well developed (fig. 4) and they contain numerous and relatively undifferentiated spermatogonia. Some of them have a conspicuous juxtanuclear aggregation of mitochondria which is not associated with the centrioles and Golgi vesicles as is the case with a true Balbiani body. Although a few small clusters of presumptive Leydig cells are found in the interstitium between 10 and 17 days, they are rare and their ultrastructure is not typical of active steroid-secreting cells : SER is poorly represented (fig. 5). Similar types of cells are also found inside the seminiferous cords, and as described originally by Scheib (1970), these Leydig cells are often amoeboid-like and appear to be migrating through the basement laminae of the testicular cords.

\section{Morphology of the female gonads in vitro}

Control. All 6-day and 8-day female control gonads differentiate into typical ovaries in vitro. Each gonad has a well developed cortex (fig. 6) containing prefollicular cells elaborating "lining bodies» (fig. 7) as well as numerous oogonia with Balbiani bodies and intercellular bridges (fig. 8). Meiotic prophase figures were not found in the sections we examined of 6- and 8-day gonads cultured for 11 and 9 days, respectively; however, numerous leptotene, and pachytene stages are present in 8-day pieces cultured for 13 days (fig. 9-10). The ovary medulla consistently develops

\section{PLATE II}

FIG. 6. - Photomicrograph of a 6-day female left control gonad after 11 days in vitro. The cortex (C) is well developed and contains a large number of typical oogonia. Large clusters of highly differentiafed interstitial cells are present in the medullary cords $(M$.$) and near the medial surface of$ the cortex $(\times 480)$.

FIG. 7. - Electron micrograph of oogonia in the cortex of the 6-day control ovary shown in figure 6. The germ cells have developed Balbiani bodies (BB) and are joined together by intercellular bridges (arrow.) $(\times 11,275)$.

FIG. 8. - Electron micrograph of "lining bodies" being produced by prefollicular cells of the inner cortex of 8-day control ovory offer 13 days in culture. These conspicuous organelles are elaborated from the plasma membrane and appear in the extracellular spaces as ovoid or horse shoeshaped particles. They consist of a double membrane with a row of ribosomal-like granules associated with the inner membrane $(\times 24,750)$.

FIG. 9. - Photomicrograph of an 8-day control ovary after 13 days in culfure. The cortex well developed contains a large number of oocytes in meiotic prophase I. In their cytoplasm, Balbiani bodies (arrows) are evident $(\times 1,060)$.

FIG. 10. - Electron micrograph of an oocyte in the cortex of an 8-day control ovary cultured for 13 days. The Docyte is in leptotene as indicated by the presence of thin threadlike chromosomes in the nucleus (arrows). Note the presence of annulatae lamellae (AL) near the Balbiani body (BB) $(\times 11,275)$. 
into a cord-like structure composed of fibroblasts, some germ cells and large clusters of highly differentiated interstitial cells (similar to fig. 2). Although these cords often resemble testicular cords, they are not limited by a basal lamina and therefore are not typical male cords.

Hormone-freated female gonads. The histological differentiation of female gonads treated with exogenous E2, $\Delta$ or DHT is, with a few ultrastructural exceptions, similar to that of confrol explants (see fig. 6). Unlike the control explants, typical chromatid bodies (fig. 11) are found in some oocyles treated with $\Delta$ and DHT but not with E2. There is also an apparent increase in the concentration of «lining bodies » in $\Delta$ and E2 treated ovaries compared to control explants (fig. 12 compare with fig. 7). In addition, typical interstitial cells are not found in any DHT-treated gonad.

\section{Morphology of male gonads in vitro}

Control. Untreated 6- and 8-day male gonads differentiate into typical testes similar to that shown in figure 13. At the end of the incubation period, each piece is surrounded by a flattened epithelial-connective tissue matrix resembling a tunica albuginea. Cortical tissue is not observed in any control explant. The medulla contains typical seminiferous cords (fig. 14) with small clusters of presumptive Leydig cells scattered throughout the interstitium (fig. 13). At the electromicroscopic level, these cells contain lipid droplets, mitochondria with tubular cristae but scarce SER (similar to fig. 5), therefore they do not exhibit the fine structure typical of active steroidsynthetizing cells.

Hormone treated. Although none of the hormonally treated male gonads were serially sectioned, a careful examination of representative thick sections suggests that 80 90 p. 100 of the 6-day, and 40-60 F. 100 of the 8-day male gonads undergo a complete

PLATE III

FIG. 11. - Electron microgroph of an oocyle in the cortex of an 8-day ovary cultured for 13 days with $\Delta$ 4-androstenedione. The oocyte is in pachytene, as indicated by the presence of the synaptinemal complex (large arrow). 2 chromatoid bodies are observed (thin arrows). They are composed of fine filaments consolidated into dense strands of varying thickness that branch and anastomose to form an irregular network. These strand-bound interstices are occupied by the ground substance of the cytoplasm and by occasional small vesicles (Fawcett ef al., 1970) $(\times 14,575)$.

FIG. 12. - Electron micrograph of prefollicular cells in the inner part of the cortex of a 6-day female left gonad cultured for 11 days with $\Delta$ 4-androstenedione. Unusually large numbers of « lining bodies » appear to be concentrated in the extraceliular spaces $(\times 24,750)$.

FIG. 13. - Photomicrograph of a 6-day control male left gonad cultured for 11 days in vitro. It has differentiated into a typical testis and contains seminiferous cords (SC) and a few presumptive Leydig cells (arrows). Note the absence of cortical tissue $(\times 320)$.

FIG. 14. - Electron micrograph of specimen shown in fig. 13. The seminiferous cords are limited by a basal membrane (arrows) and contain numerous spermatogonia ( $\mathrm{Sg}$.) and prospective Sertoli cells. Note the presence of anulate lamellae $(\mathrm{AL})$ in the germ cell. $(\times 6,300)$. 
or partial sex reversal when incubated with either E2, $\Delta$ or DHT. The remaining gonads in each experiment apparently differentiate into typical testes.

All 6-day sex-reversed gonads are surrounded by a well-developed ovarian cortex similar to that shown in figure 6. In each 8-day explant, the amount of cortical tissue varies considerably, ranging from a few small patches to a more or less complete ovarian-like cortex (fig. 15). However, regardless of the amount of cortex induced by E2, $\Delta$ or DHT, the male cortical cords contain numerous germ cells which resemble typical oogonia with Balbiani bodies and intercellular bridges (fig. 16). In E2 or $\Delta$ sex-reversed gonads prefollicular cells elaborate «lining bodies ». Although DHTtreated gonads develop an unusually thick cortex, the prefollicular cells produce relatively few " lining bodies " and contain excessive amounts of rough ER cisternae filled with a granular substance (fig. 17). In addition, their nuclei have one or several nucleoli with outstanding fibrillar centres. Meiotic prophase figures and chromatoid bodies are not observed in any male explant. The medulla in 6- and 8-day sex-reversed gonads rqnges from well organized seminiferous cords to massive cord-like aggregations similar to those described in cultured ovarian explants. Despite this variability, E2 and $\Delta$ sex-reversed explants contain numerous clusters of ovarian-like interstitial cells scattered throighout the medullary cords. In contrast no typical interstitial cells were observed in DHT-treated explants.

\section{Discussion.}

The results of the present study confirm and extend previous observations (Wolff and Haffen, 1952 ; Erickson, 1974a) by demonstrating that the ultrastructural differentiation of male and female gonads cultured in vitro is similar to that of normal male and female gonads in ovo. Moreover these results verify the original thesis proposed by Wolff and Haffen (1952) that the factors regulating the differentiation of the bird prospective male and female gonads reside within the gonads themselves.

Although in general, the differentiation of female gonads treated with E2, $\Delta$ or DHT is similar to that of control pieces, some differences should be pointed out:

\section{PLATE IV}

FIG. 15. - Photomicrograph of an 8-day male gonad treated for 9 days with DHT. It contains a well developed cortex which is packed with large numbers of oogonia $(\times 320)$.

FIG. 16. - Electron micrograph of a 6-day male gonod treated for 11 days with DHT. The male germ cells have differentiated into female-like oogonia $(\mathrm{O} \circ \mathrm{g}$.) with Balbiani bodies (BB) and intercellular bridges (arrow.) $(\times 15,125)$.

FIG. 17. - Electron micrograph of prefollicular cells in the surface of the cortex of an 8-day testis cultured for 9 days with DHT. Large amount of dilated RER (thin arrows), whose cisternae are filled with a granular protein-like substance is observed. Note the presence of large fibrillar centres (large arrows) in the nucleoli. These areas of low electron density are surrounded by the fibrillar com. ponent $(F)$ and the granular component $(G).(\times 14,575)$. 
1) We observed chromatoid bodies in meiotic germ cells of ovaries treated with $\Delta$ or DHT, but not in oocytes of control female gonads. These chromatoid bodies are thought to be a specialized and transitory form of the "nuage " (Eddy, 1974, 1975) and have been observed in spermatocytes and spermatids of a variety of different species (Fawcett et al., 1970 ; Eddy, 1974, 1975). Therefore, in our experiments it could be tempting to correlate the occurrence of chromatoid bodies with high levels of exogenous steroids present in the culture media. 2) There is an apparent increase in the concentration of « lining bodies " in E2 and $\Delta$ treated ovaries. In view of the fact that female gonads incubated with $\Delta$ (an aromatizable androgen, Engel, 1975) produce high levels of estrogen (Erickson, unpublished results) it might be suggested that the apparent increase of «lining bodies» is correlated with estrogen levels. A correlation between "lining body 》 production and circulating levels of female hormones has not, however, been observed in the adult hen (Schjeide et al., 1974). 3) Typical steroid secreting cells are not found in female gonads treated with DHT (a potent competitive inhibitor of androstenedione and testosterone aromatization, and a non-aromatizable androgen in the human placenta, Thompson and Siiteri, 1974). Since radioimmunoassay data (Erickson, unpublished results) show that DHT causes a dramatic reduction ( $\geqslant 75$ p. 100) in E1 and E2 accumulation in 6- and 8-day ovarian cultures, this ultrastructural deficiency could be correlated with a marked perturbation of steroidogenesis.

Under the culture conditions described here, E2, $\Delta$ or DHT induce various degrees of sex-reversal in male embryonic gonads cultured in vitro. Thus, our in vitro results confirm at the ultrastructural level earlier in ovo reports that estrogen (Narbaitz, 1971) $\Delta$ (Wolff et al., 1948) and DHT (Weniger and Zeis, 1973) induce a sex-reversal in undifferentiated male gonads. The fact that one of us (Erickson, 1974b) reported a "spontaneous » sex-reversal in organ culture of embryonic male chicken gonads apparently conflicts with our present data. Nevertheless it should be emphasized that the author suggested the fetal calf serum used in the culture media may have contained trophic agents, perhaps estrogen, which caused the sex-reversal, whereas in the present study the concentration of estrogens and other steroids measured in the final growth medium was $<20 \mathrm{pg} / \mathrm{ml}$.

The mechanism by which the 3 different steroids induce a sex-reversal in the male pieces is not understood. It has been postulated by Wolff and Ginglinger (1935) that estrogen induces the differentiation of the germinal epithelium into a cortex. This would imply the germinal epithelium male or female is a target tissue for estrogens. Then, the sex-reversal induced by E2 could be explained by direct interaction of estrogen with the somatic cells and or germ cells into the male epithelium causing them to differentiate into prefollicular cells and oogonia respectively. Further experiments are required to test this possibility.

Although some of our data (male gonads treated with $\Delta$ : aromatizable androgen) are consistent with the possibility that sex-reversal induced by androgens results from a stimulation in estrogen production by the male gonad, one cannot exclude the possibility these androgens act directly on the germinal epithelium itself. We raise the question because the most extensive sex-reversal observed in the present study is produced by DHT. 1) As it was already emphasized, it is a potent competitive inhibitor of $\Delta$ and testosterone aromatization and a non-aromatizable androgen. 2) No 
estrogen production was defected in our male gonad cultures incubated with DHT (Erickson, unpublished results). 3) The prefollicular cells developed within the male DHT-treated explants display cytoplasmic and nuclear features strongly suggesting an active protein synthesis and recently Goessens (1976) correlated the presence of fibrillar centres in the nucleoli of cells in which RNA synthesis is very active. 4) Recent studies (Schmidt et al., 1976 ; Rochefort and Garcia, 1976 ; Garcia and Rochefort, 1977) performed in the uterus of the rat indicate that both DHT and testosterone used at pharmacological doses are capable of inducing the synthesis of a specific uterine protein IP which under normal conditions is inducible only by E2. In addition, Garcia and Rochefort demonstrated that in these conditions androgens interact with estradiol receptors and that the interaction results in the induction of a specific estrogenresponse (IP synthesis). If the male germinal epithelium is, indeed, a target tissue for estrogen, then one could postulate that high levels of exogenous androgens and particularly DHT present in the culture might interact with the male germinal epithelium in a way that initiates an estrogen-like response, i.e. the differentiation of a cortex with prefollicular cells and oogonia.

\section{Conclusion.}

It should be emphasized that bird embryonic male gonads at the early stages of their development (unlike female gonads) have a limited capacity to synthesize steroids (reviewed by Haffen, 1975 ; Erickson, unpublished results), and this can be correlated with the relatively small amounts of steroid-secreting cells in the male developing testis and the apparent absence in these cells of large activity evidenced by a scarce SER in ovo or in vitro (in contrast to female gonads). Furthermore, 6-day (or 8-day in many cases) male gonads incubated with pharmacological doses of estrogen (E2) or androgens ( $\triangle$ or DHT) undergo sex-reversal. In view of these results it is still in doubt whether or not androgens play a role in controlling the initial stages of testicular differentiation.

\footnotetext{
27 e Congrès international des Sciences physiologiques, Symposium " Germ and somatic cell interaction " Paris, 21-23 juillet 1977.
}

Acknowledgments. - This work was supported by Rockefeller Foundation Grant RF 72007 ; Grant HD 02344 from the National Institutes of Health, and Contrat DGRST No 75.7 .0013 .

We thank Drs Don Fawcett and Ken Ryan for their interest and support in this research project, Mrs Lisette Laurens for typing the manuscript and C. Crotte for photographic assistance.

Résumé. Des explants de gonades gauches d'embryons de Poulet mâles et femelles sont cultivés en présence ou en l'absence de : androstènedione $(\Delta)$ dihydrotestostérone (DHT) et œstradiol (E2).

Dans les cultures témoins les gonades femelles se différencient en ovaires. Dans le cortex, les cellules préfolliculeuses élaborent des «lining bodies», les cellules germinales différencient des corps vitellins de Balbiani, des ponts intercellulaires et leurs noyaux pré- 
sentent des figures de prophase I méiotique. Le cortex ovarien des gonades femelles traitées par les stéroïdes est semblable à celui des témoins.

Dans les cultures témoins les gonades mâles se différencient en testicules. Aucun tissu cortical n'est observé. Dans la plupart des cas, le traitement par E2, $\Delta$ ou DHT produit des degrés divers d'inversion du sexe. Dans le cortex ovarien induit, les cellules germinales ont l'aspect d'ovogonies. L'ultrastructure des cellules préfolliculeuses différenciées sous l'action de $\Delta$ et E2 est identique à celle observée chez les femelles témoins. Bien que DHT produise une féminisation massive du cortex, les cellules préfolliculeuses ont un aspect particulier. Elles ne développent que peu de «lining bodies», elles contiennent de gros nucléoles avec de remarquables centres fibrillaires, enfin leur cytoplasme contient de grandes quantités de citernes de RER remplies d'une substance finement granuleuse. Tous ces critères suggèrent une synthèse protéique active.

Ces résultats appuient l'hypothèse du rôle que les stéroïdes peuvent jover dans la régulation de la différenciation de l'ovaire d'oiseau. La différenciation des cellules germinales mâles en « ovogonies » pourrait être rapprochée d'une action directe ou indirecte des œstrogènes ou androgènes exogènes sur le corlex ovarien qui s'élabore. L'aspect singulier des gonades mâles féminisées par l'action de DHT pourrait réellement suggérer une action directe des stéroïdes sur les cellules préfolliculeuses. Enfin ces résultats peuvent laisser subsister un doute sur le rôle joué par les androgènes dans la régulation des stades précoces de la différenciation testiculaire.

\section{References}

AKRAM H., WENIGER J. P., 1967. Sécrétion d'œstrone et d'œstradiol par le testicule féminisé de l'embryon de poulet. C. R. Acad. Sci., Paris Sér. D., 264, 1806-1807.

AKRAM H., WENIGER J. P., 1969. Sécrétion d'œstrone et d'œstradiol par les gonades embryonnaires d'Oiseaux. Gen. comp. Endocrin., 12, 568-573.

CARLON N., MIRRE C., STAHL A., 1974. Aspects ultrastructuraux du cytoplasme de la cellule germinale femelle chez l'embryon de poulet. C. R. Acad. Sci., Paris Sér. D., 279, 1081-1083.

CHALLIS J. R. G., DAVIES I. J., RYAN K. J., 1973. The concentration of progesterone, estrone and estradiol-17 $\beta$ in the plasma of pregnant rabbits. Endocrinology, 93, 971-975.

CHALLIS J. R. G., DAVIES I. J., BENIRSCHKE K., HENDRICKX A. G., RYAN K. J., 1975. The effets of dexamethasone on the peripheral plasma concentrations of androstenedione, testosterone and cortisol in the pregnant Rhesus monkey. Endocrinology, 96, 185-192.

DANTCHAKOFF V., 1935. Sur l'inversion sexuelle expérimentale de l'ébauche ovarique chez l'embryon de poulet. C. R. Soc. Biol. Paris, 151, 1088-1089.

EDDY E. M., 1974. Fine structural observations on the form and distribution of Nuage in germ cells of the rat. Anat. Rec., 178, 731,-758.

EDDY E. M., 1975. Germ plasm and the differentiation of the germ cell line. Int. Rev. Cytol., 43, 229-279.

ENGEL L. L., 1975. The biosynthesis of estrogen, 467-484. In GREEP R. O., Handbook of Physiology, Sect. 7, Endocrinology, Vol. II, Female Reproductive Sysfem, part I. Physiol. Soc. Washington, D. C.

ERICKSON G. F., 1974a. The control of the differentiation of female embryonic germ cells in the bird. Develop. Biol., 36, 113-129.

ERICKSON G. F., 1974b. "Spontaneous " sex reversal in organ cultures of the embryonic male gonad of the bird. J. Embryol. exp. Morph., 31, 611-620.

FAWCETT D. W., EDDY E. M., PHILLIPS D. M., 1970. Observations on the fine sucture and relationships of the chromatoid body in mammalian spermatogenesis. Bis Reprod., 2, 129-153.

GARCIA M., ROCHEFORT H., 1977. Androgens on the estrogen receptor. II. Correlation between nuclear translocation and uterine protein synthesis. Steroids, 29, 111-124.

GOESSENS G., 1976. The nucleolar fibrillar centres in various cell types in vivo or in vitro. Cell Tiss. Res., 173, 315-324. 
HAFFEN K., 1970. Sexual differentiation and intersexuality in vitro, 121-175. In THOMAS J. A. Organ Culture. Acad. Press, New York.

HAFFEN K., 1975. Sex differentiation of avian gonads in vifro. Amer. Zool., 15, 257-272.

NARBAITZ R., 1971 . Ultrastructural aspects of cortical differentiation in chick ovaries and intersexual gonads. $Z$. Zellforsch., 118, 315-325.

NARBAITZ R., ADLER R., 1966. Submicroscopical observations on the differentiation of chick gonads. J. Embryol. exp. Morphol., 16, 41-47.

RAHIL K. S., NARBAITZ R., 1972. Evolution of the lining bodies in the embryonic chick gonad. J. Embryol. exp. Morph., 28, 133-140.

ROCHEFORT H., GARCIA M., 1976. Androgen on the estrogen receptor. I. Binding and in vivo nuclear translocation. Steroids, 28, 549-560.

SCHEIB D., 1970. Sur la présence de cellules « interstifielles primaires " dans les cordons du testicule de l'embryon de poulet. C. R. Acad. Sci., Paris, Sér. D., 270, 123-125.

SCHJEIDE O. A., HANZELY L., HOLSHOUSER S. J., BRILES W. E., 1974. Production and fates of unique organelles (transosomes) in ovarian follicles of Gallus domesticus under various conditions. Cell Tiss. Res., 156, 47-59.

SCHMIDT W. N., SADLER M. A., KATZENELLENBOGEN B. S., 1976. Androgen-uterine interaction : nuclear translocation of the estrogen receptor and induction of the synthesis of the uterineinduced protein (IP) by high concentrations of androgens in vifro, but not in vivo. Endocrinology, 98, 702-716.

THOMPSON E. A., SIITERI P. K., 1974. The involvement of human placental microsomal cytochrome P-450 in aromatization. J. biol. Chem., 249, 5373-5378.

WENIGER J. P., ZEIS A., 1973. Induction de la production d'œstrogènes dans le testicule embryonnaire de poulet par la dihydrotestostérone. Biochimie, 55, 1163-1164.

WILLIER B. H., GALLAGHER T. F., KOCH F. C., 1935. Sex modification in the chick embryo resulting from injection of male and female hormones. Proc. nat. Acod. Sci. (Wosh.), 21, 625-631.

WOLFF Et., GINGLINGER A., 1935. Sur la transformation des poulets mâles en intersexués par injection d'hormone femelle (follieuline) aux embryons. Arch. Anat. Histol. Embryol., 20, 219-278.

WOLFF Et., HAFFEN K., 1952. Sur la différenciation sexuelle des gonades embryonnaires de l'embryon de poulet en culture in vitro. Ann. Endocr., 13, 724-731.

WOLFF Et., STRUDEL G., WOLFF Em., 1948. L'action des hormones androgènes sur la différenciation sexuelle des embryons de poulet. Arch. Anat. Histol. Embryol., 31, 237-310. 